\title{
The Impact of Strategic Alliance Partner Characteristics on Firms' Innovation: Evidence from Jordan
}

\author{
Ahmad Nasser Ahmad Abuzaid ${ }^{1}$ \\ ${ }^{1}$ Faculty of Economic and Administrative Sciences, Alzarqa University, Jordan \\ Correspondence: Ahmad Nasser Ahmad Abuzaid, Faculty of Economic and Administrative Sciences, Alzarqa \\ University, Alzarqa, Jordan. Tel: 962-795-665-538. E-mail: ahmad.abuzaid2007@yahoo.com
}

Received: December 5, 2013

Accepted: January 13, $2014 \quad$ Online Published: February 21, 2014

doi:10.5539/ijbm.v9n3p77

URL: http://dx.doi.org/10.5539/ijbm.v9n3p77

\begin{abstract}
The aim of this study is to examine the impact of strategic alliance partner characteristics namely (partner complementarity, partner commitment, and partner compatibility) on firm's innovation, which includes incremental innovation and radical innovation. The population of the study contained (13) Jordanian Pharmaceutical companies, and the sample unit consisted from (122) managers and head of divisions working in strategic alliances, marketing and production areas within the target companies. In order to gathering the data required for measuring the study variables a questionnaire was developed. The results of the study showed that the strategic alliance partner characteristics had a significant impact on the Jordanian pharmaceutical companies' innovation, and the impact of alliance partner characteristics (Compatibility, Capabilities, and Commitment) on incremental innovation is more than the impact on radical innovation. Also the results showed that the complementarity of partner has the highest impact on the firm innovation, then the compatibility, then the commitment. Based on these findings the study recommending that the companies that seeking for innovation through a strategic alliances must select the appropriate partner who has a complementary capabilities that contribute non overlapping resources to the relationship, and a partner who has the unique competencies; and the partner who has a compatible strategic objectives, organization culture and management style; and the partner who has a strong sense of commitment for the alliance.
\end{abstract}

Keywords: strategic alliances, alliance partner, partner characteristics, radical innovation, incremental innovation

\section{Introduction}

Innovation now is considered as the most significant engine of competitive success in many industries; the increasing importance of innovation is traced partially to the markets globalization. Firms are required to innovate constantly to differentiate their products and services in order to encounter the pressure of foreign competition. Introducing new products help firms protect their margins, while investing in process innovation helps firm lower their cost.

Strategic alliances considered as important in increasing the firm's internal innovative activities (Deeds \& Rothaermel, 2003). From the current literature, it is obvious that firms can enhance their innovative capabilities by establishing strategic alliances with diverse partners. The circulations of strategic alliances in the pharmaceutical industry propose that uncertainty of environment is high. The product innovation high level in this industry is the main factor contributing to the competitive uncertainty high levels. By using of alliances, firms can get the most important resources beyond of the individual cooperating firm's capabilities (Byrne, 1993). Usually, these partnerships bring together organizations with complementary core competencies that enable them to develop new products and creating new processes (Mason, 1993).

After a firm has made the decision to participate in a strategic alliance, the next crucial decision is its choosing of a proper partner (Hitt, Tyler, Hardee, \& Park, 1995). Prior researches propose that many of strategic alliances failure can be attributed to the chosen of the partner. And deriving value from strategic alliances needs firms to choose the appropriate partners (Reuer, 1999). In choosing appropriate partners, strategic alliances scholars identified many criteria and factors that can be used to guarantee successful pre-selection of strategic alliances partner (Wu, Shih \& Chanm, 2009; Shah \& Swaminathan, 2008; Bierly \& Gallagher, 2007; Hagen, 2002; Kanter, 1994). These criteria and factors are recognized as significant determinants of firm's and strategic alliances performance. whereas these topics have been studied differently in varied interorganisational 
circumstances, most of the studies focus on their effects on the alliance success and performance, and firm performance in terms of profitability or numbers of patents and there is not sufficient studies has been done to examine empirically how they (as a selection criteria of partner for ongoing alliances) effects on the innovation performance of the Jordanian pharmaceutical industry by using subjective measures.

In this study, to deal with this specified gap in the strategic alliance literature the Jordanian pharmaceutical companies studied because those companies participated in many strategic alliances after the Jordan assigned the agreement on trade related aspects of intellectual property rights (TRIPS). And the main objective of this study was to examine if there is a significant impacts for the characteristics of strategic alliance partner on firm innovation, in order to answer the main study question: what is the impact of strategic alliance partner characteristics on firm innovation?

\section{Literature Review}

\subsection{Strategic Alliance Partner Characteristics}

Gulati (1998) defined strategic alliances as voluntary arrangements among organizations involving exchange, sharing, or codevelopment of products, technologies, or services. After a firm has made the decision to participate in a strategic alliance, the next crucial decision is its choosing of a proper partner (Hitt et al., 1995). Chosen of partners is one of the critical decisions connected to the strategic alliances (Ireland, Hitt \& Vaidyanath, 2002; Hitt et al., 1995). Selection of partner identifies alliance operating policies and procedures, skills mix of alliance's, the needed knowledge, and resources, and its vulnerability to local circumstances, structures, and institutional modifications (Child \& Faulkner, 1998) that are required to enhance firm's innovation performance. And many of strategic alliances failure can be attributed to the chosen of the partner at the stage of planning; because at this stage should be dealt with risk minimization. Shah and Swaminathan (2008) through a review of more than (40) studies found that the following characteristics of partner have a positive effect on strategic alliances performance: partner complementarity, partner commitment, and partner compatibility or fit.

\subsubsection{Compatibility}

The extent of compatibility between partner firms has been found to be a significant indicator of the success or failure of joint ventures as one of the strategic alliances forms (Shamdasani \& Sheth, 1995). The concept of compatibility including a wide issues such as strategic ground, hopes for the future, values and principles (Kanter, 1994), organizational and cultural matters (Shamdasani \& Sheth, 1995).

The compatibility of partners can be defined as the fit among alliance partners' organizational culture, the similarity of strategic goals, and working styles that smooth coordination of strategic alliance activities and implementation the strategies of alliance.

\subsubsection{Complementarity}

Organization considers as a combination of capabilities and unique resources that present the foundation for its strategy and is the major source of its profits according to firm resource-based view. The capabilities arise after a while through complex interactions between and among tangible and intangible resources, and they embody an organization's capacity to diffuse resources that have been purposely integrated to achieve a desired end state and they embody an organization's capacity to deploy resources that have been purposely integrated to attain a desired end state (Hitt, Ireland, \& Hoskisson, 1997). Moreover knowledge and skills considered as the main basis of an organization's capabilities that are usually developed in specific functional areas like research and development, marketing and advertising, and manufacturing. So, an important trait in strategic alliances is if a partner has the operational capability in the form of resources and core-competencies (Hitt et al., 1997). The matter of capabilities in strategic alliances is related to the complementarity.

The complementarity of partner is the degree to which a partner shares non overlapping resources to the alliance, like that one partner provides those value-chain resources or capabilities the other needs it (Dyer \& Singh, 1998; Harrigan, 1988). The highest complementarity among partners will leading to the highest success possibility of alliance according to the firm resource-based perspective.

\subsubsection{Commitment}

Commitment considered as the essential part to the success of alliance (Hagen, 2002). Commitment described as a promise by strategic alliance partners to undertake certain actions that will smooth the achievement of the alliance's strategic goals (Shamdasani \& Sheth, 1995). And it appears especially significant in strategic alliances where partners have determined the particular benefits they anticipate to earn by working together, but 
stay relatively ambiguous about the exact processes needed to attain them. Partner commitment in these strategic alliance relationships is more significant than normal, as partners must be willing to devote costly resources to the relationship and promise to work with each other even when they recognize that some adjustment might be wanted in the future in light of the uncertainty that exists (Kale \& Singh, 2009). Thus, the commitment of partners is appear through the degree to which a partner is interested and capable to commit resources (time, tangible and intangible) to achieve the strategic alliance goals and objectives, and be able to show the willingness and intention to preserve the alliance.

\subsection{Firm Innovation}

According to (Utterback, 1994) Innovation considers as a crucial strategic thrust that plays a significant role in the firm's survival and prosperity at all firm sizes and in every industry. As the business environment becomes increasingly uncertain and competitive the importance of innovation will continuously grow in the future.

There are many definitions for innovation in the literature; but, the majority of these definitions share common topics linking to creative ideas, which may be turned into new products, processes and services to improve competitive advantage and meet customers' changing needs (Nystrom, 1990). One of the innovation definitions that the innovation is something that is new or improved done by an enterprise to create significantly added value either directly for the enterprise or directly for its customer (Carnegie \& Butlin, 1993). Many scholars argue that Innovation is more than the generation of creative ideas; it is the practical implementation of those ideas into some new device or process (Schilling, 2008).

Researchers have suggested many classifications of innovation: 1) administrative vs. technical (Kimberly \& Evanisko, 1981) based on the objective of innovation adoption; 2) competence enhancing vs. competence destroying (Gatignon, Tushman, Smith, \& Anderson, 2002) based on innovation's effect on a firm's competencies; 3) product vs. processes (Schilling, 2008) based on organization outputs and the way an organization conduct its business; and 4) radical vs. incremental (Dewar \& Dutton, 1986; Ettlie, Bridges \& O'Keefe, 1984) based on the extent of change to technology. Among them, the last classification, radical innovation versus incremental innovation, has recently received much attention from researchers who are interested in organizational learning and dynamic capability (e.g.,,, Benner \& Tushman, 2003; Danneels, 2002).

Incremental innovation and radical innovation collectively determine an organization's dynamic capability which can influence its competitive advantage (Benner \& Tushman, 2003). Accordingly, it becomes imperative to achieve high performance in both incremental and radical innovation. Under the current competitive and turbulent environments, organizations need to innovate faster, better, and cheaper (Swink, Talluri \& Pandejpong, 2006).

\subsubsection{Incremental Innovation}

According to (Garcia \& Calantone, 2002; Koberg, Detienne \& Heppard, 2003) incremental innovation defined as product improvements and line extensions that are designed to meet the needs to existing customers or markets. It includes the products that provide new features, benefits, or improvements to the existing technology in the existing market. Incremental innovation might not be particularly new or exceptional; it might have been previously known to the firm or industry, and involve only a minor change from (or adjustment to) existing practices.

\subsubsection{Radical Innovation}

Radical innovation is defined as product innovations that are new to the firm and/or the industry, and offer substantial new benefits to customers. It embodies a new technology that results in a new market infrastructure (Chandy \& Tellis, 2000). The radicalness might be conceived as the combination of newness and the degree of differentness. A technology could be new to the world, new to an industry, new to a firm, or new merely to an adopting business unit. A technology could be significantly different from existing products and processes or only marginally different. The most radical innovations would be new to the world and exceptionally different from existing products and processes.

\section{The Relationship between Strategic Alliances and Firm Innovation}

Innovation can arise from many different sources; the most important of theme is strategic alliances. Previous researches had found strategic alliances to be an important driver of firms innovation (Sivadas \& Dwyer 2000; Wuyts, Dutta \& Stremersch, 2004), Past studies have found high correlations among the strategic alliances and firms innovation performance (e.g., Kelly \& Rice, 2002), and show that alliances contribute to firms product innovativeness (Kotabe \& Swan, 1995). And there are many empirical studies conducted to examine the relationship between different aspects of strategic alliances and firm innovation. Cui \& O'Connor (2012) in their 
study takes a portfolio approach to examine the resource diversity of multiple alliance partners and its contribution to firm innovation. They examine factors that may facilitate or inhibit information and resource sharing across alliances and thus influence the realization of any benefit of portfolio resource diversity. The model identifies various factors along three dimensions, including the composition of an alliance portfolio, alliance management and the market environment that moderate the relationship between alliance portfolio resource diversity and firm innovation. The researchers use the survey instrument from Fortune to measure the level of firm innovation. The study did not find a significant main effect of resource diversity on firm innovation because of the interdependence between these variables. Faems and Looy and Debackere (2005) in their study examined the relationship between interorganisational collaboration in terms of (exploitative-oriented and explorative oriented collaborations) and different types of firm innovation outcomes. The results showed that firms that possess a heterogeneous network of collaborative partners within the framework of their innovation strategies perform better in terms of the proportion of turnover realized by means of new or improved products, and the exploitative-oriented collaborations support the improvement and further development of existing technologies and products, while explorative oriented collaborations would be beneficial for innovation objectives aimed at creating new technologies and products. Sampson (2007) in his study examined the impact of partner technological diversity and alliance organizational form on firm innovative performance. The study found that the alliances contribute to firm innovation when technological diversity is moderate, rather than low or high; also the study found that the equity joint venture improves firm benefits from alliances with high levels of technological diversity. Thus, alliance organizational form likely influences partner abilities and incentives to share information which affects innovation performance in terms of patents. Qing and Weijing and Wenhui (2012) in their study examined the relationship between alliance partner selection in terms of (reputation, compatibility and technological standardization ability) and innovation performance in terms of (patents) of technological standard alliance in China. The study found that the selection of alliance partners would directly affect the operations and management of technological standard alliances in China, and appropriate partners among technological standard alliances will play a significant role in improving partners' independent innovation capability. The empirical results showed that the potential cooperative partners' reputation, compatibility and standardization ability had an obvious effect on innovation performance. Phelps (2010) in his study examined the influence of the structure and composition of a firm's alliance network on its exploratory innovation - innovation embodying knowledge that is novel relative to the firm's extant knowledge. The results indicated that the technological diversity of firm's alliance partners increases its exploratory innovation. Further, network density among firm's alliance partners strengthens the influence of diversity. These results suggest the benefits of network "closure" (wherein a firm's partners are also partners) and access to diverse information can coexist in an alliance network and that these combined benefits increase exploratory innovation. Caner and Tyler (2013) in their study investigated the contribution of alliance portfolio R\&D intensity to the firm's number of new products introduced; the study found that the R\&D intensity of alliance portfolio related to the firm products innovations and introductions, also the study found that the R\&D intensity of alliance portfolio has a more positive impact on the pharmaceutical companies new products innovation and introduction than those of biotechnology companies. Zheng, Li and $\mathrm{Wu}$ (2013) investigated the correlation between network resources and innovation performance of Chinese manufacturing firms, the study found that there is a direct contribution of network resources to firm's innovation performance.

\section{Study Hypotheses}

The study is mainly aimed at investigating the impact of strategic alliance partner characteristics on firm innovation. Therefore, the main hypothesis is:

Ho: There is no impact with statistical significant at $(\alpha \leq 0.05)$ of strategic alliance partner characteristics on the innovation of Jordanian pharmaceutical companies. This hypothesis generates the following sub-hypotheses:

H01: There is no impact with statistical significant at $(\alpha \leq 0.05)$ of strategic alliance partner characteristics (compatibility, complementarity, and commitment) on the incremental innovation of Jordanian pharmaceutical companies.

H02: There is no impact with statistical significant at $(\alpha \leq 0.05)$ of strategic alliance partner characteristics (compatibility, complementarity, and commitment) on the radical innovation of Jordanian pharmaceutical companies.

\section{Methodology}

According to the nature of this study and its objective which include the identification of the impact of strategic alliance partner characteristics on firm innovation from the perspective of workers in target companies the 
researcher used both the descriptive methodology by reviewing the literature related to the study variables and analytical methodology by analyzing the data collected through the questionnaire distributed.

\subsection{Study Population and Sample}

The population of the study composed of (13) Jordanian pharmaceutical company from (16) company working in this industry in Jordan, where there is two companies rejected to cooperate with the researcher and one of them under construction. The size of the study sample was (122) manager and head of division who's their working nature related to the strategic alliances, marketing and production areas within the target companies. The characteristics of the study population introduced in Table 1 and the characteristics of study sample introduced in Table 2 .

Table 1 . The characteristics of study population

\begin{tabular}{|c|c|c|}
\hline Variable & Category & Number of companies \\
\hline \multirow[t]{2}{*}{ Scope of market coverage } & Regional & 2 \\
\hline & International & 11 \\
\hline \multirow{4}{*}{$\begin{array}{l}\text { Number of strategic alliances the company } \\
\text { involved in it }\end{array}$} & Less than ( 5) alliances & 2 \\
\hline & From (5) to less than (10) alliances & 6 \\
\hline & From (10) to less than (15) alliances & 3 \\
\hline & (15) alliances and above & 2 \\
\hline Total & & 13 \\
\hline
\end{tabular}

Table 2. The characteristics of study sample

\begin{tabular}{llll}
\hline Variable & Category & Frequency & Percentage \\
\hline Position title & General manager & 10 & 8.20 \\
& Director of department & 52 & 42.62 \\
& Head of division & 60 & 49.18 \\
Years of experience & Less than ( 5) years & - & - \\
& From (5) to less than (10) years & 23 & 18.85 \\
& From (10) to less than (15) years & 42 & 34.43 \\
& From (15) to less than (20) years & 48 & 39.34 \\
Total & (20) years and above & 9 & 7.38 \\
\hline
\end{tabular}

\subsection{Study Instrument}

The study instrument was developed by reviewing the literature, and the questionnaire consisted of three parts: The first part covers the demographic variables of the study sample and population, such as position, experience, the scope of market coverage, and number of strategic alliances that a company involved in it. The second part includes the items related to the characteristics of strategic alliance partner which adopted from (Kale \& Singh, 2009; wu et al., 2009; Pansiri, 2008). The third part covers the perceived innovation performance of the company that includes radical innovation which measured by (5) items that adopted from ( $\mathrm{Li}, \mathrm{Liu}, \mathrm{Li}, \& \mathrm{Wu}$, 2008; Dewar \& Dutton 1986; Ettlie, 1983). And incremental innovation which measured by (4) items that adopted from (Li et al., 2008; Dosi, 1982; Herbig, 1994). The answers to the second and third part of questionnaire relied on a Likert's Scale, ranging from strongly disagree (1); disagree (2); moderately degree (3); I agree (4); and strongly agree (5).

\subsection{Instrument's Validity}

The researcher consulted some academicians and experts during the preparation phase of the research and according to their opinions the questionnaire is fit to the current study.

\subsection{Instrument Reliability}

The researcher tested data reliability to ensure producing dependable results and reliability for the measurement instrument. Reliability was determined by the Chronbach alpha test. The alpha value was $(0.89)$, and this value 
is excellent because it is higher than the acceptable value of (60\%), implying consistency among responses and instrument reliability $(0.89)$.

\section{Results and Discussion}

\subsection{Data Presentation}

The means and standard deviations for the respondent's answers on the questionnaire items related to characteristics of strategic alliance partner and perceived innovation introduced in Table 3 and Table 4. Under each table the results was interpreted and discussed.

Table 3. The means and standard deviations for the respondent's answers on the characteristics of strategic alliance partner

\begin{tabular}{|c|c|c|}
\hline Compatibility & Means & Standard Deviation \\
\hline 1.We choose our partner because our organization culture was compatible & 3.40 & 1.100 \\
\hline 2. We choose our partner because our strategic objectives was compatible & 3.82 & 0.996 \\
\hline 3. We choose our partner because our management styles was compatible & 3.32 & 1.232 \\
\hline Average & 3.51 & - \\
\hline \multicolumn{3}{|l|}{ Complementarity } \\
\hline 4.Our partner has unique competencies that we need & 3.90 & 1.068 \\
\hline 5. Our partner has higher level of technical capabilities that we need & 3.68 & 1.127 \\
\hline 6. Our partner has wider market coverage & 3.41 & 1.118 \\
\hline 7. Our partner has diverse customer & 3.05 & 1.454 \\
\hline 8. Our partner has the quality distribution system & 3.47 & 1.005 \\
\hline $\begin{array}{l}\text { 9. We choose our partner because there were possible synergies perceived in working } \\
\text { together }\end{array}$ & 3.89 & 0.805 \\
\hline 10. We choose our partner because we had complementary assets & 3.82 & 1.107 \\
\hline Average & 3.60 & - \\
\hline \multicolumn{3}{|l|}{ Commitment } \\
\hline $\begin{array}{l}\text { 11. Our partner is willing to dedicate whatever resources it takes to make the alliance a } \\
\text { success }\end{array}$ & 3.42 & 0.995 \\
\hline 12. Our partner is quite willing to make long-term investment in the alliance & 3.16 & 1.158 \\
\hline 13. Our partner has a strong sense of loyalty to the alliance & 3.62 & 1.023 \\
\hline 14. Our partner is willingness to share expertise & 3.47 & 1.184 \\
\hline Average & 3.42 & - \\
\hline
\end{tabular}

As shown in table 3 the results indicate that the Jordanian pharmaceutical companies focus on selecting the partner who has compatible strategic objectives (mean 3.82) in order to have an alliance that could be maintained for the longer term, and then on the partner who has organization culture with mean (3.40) but on other hand the results indicate that there is less emphasis on partners having compatible management styles (mean 3.32) despite the importance of this factor in innovation processes. Also the results from table 3 indicate that the target companies focus on selecting a partner who has unique competencies with mean (3.90) and then on a partner who there were possible synergies perceived in working with him (mean 3.89) and then on the partner who has complementary assets (mean 3.82) and that make a sense because the innovation processes need this requirements, but on the other hand this companies give a less importance for a partner who has diverse customer (mean 3.05) despite the importance of customers diversity in innovation processes. Finally, the results from table 3 indicate that the target companies focus on selecting the partner who has a strong sense of loyalty to the alliance (mean 3.62) and then on the partner who willingness to share expertise (mean 3.47) and then on the partner who is willing to dedicate whatever resources it takes to make the alliance a success (mean 3.42) and put less focus on the partner who is quite willing to make long-term investment in the alliance with mean (3.16). 
Table 4. The means and standard deviations for the respondent's answers on the perceived innovation

\begin{tabular}{lcc}
\hline Radical innovation & Means & Standard Deviations \\
\hline 15.We create completely new products more than our competitors & 3.20 & 1.139 \\
16. We introduce radically new functions in products more than our competitors & 3.24 & 1.123 \\
17.We often develop new technologies & 2.96 & 1.225 \\
18. We often introduce new technologies successfully into the industry & 3.27 & 1.115 \\
19.We are often the creator of new procedure skills & 2.94 & 1.298 \\
20.We are often the creator of new techniques skills & 2.93 & 1.315 \\
21.We often introduce completely new products in the new market & 3.34 & 1.093 \\
Average & 3.13 & - \\
Incremental innovation & & 0.992 \\
22.We create novel patterns of products more than our competitors & 3.41 & 0.811 \\
23.We improve existing products more than our competitors & 3.80 & 0.901 \\
24.We improve existing process more than our competitors & 3.77 & 1.054 \\
25.We exploit existing technologies deeply more than our competitors & 3.52 & 1.023 \\
26.We introduce incrementally new products in the market & 3.37 & - \\
Average & 3.57 &
\end{tabular}

As shown in table 4 the results indicate that the Jordanian pharmaceutical companies introduced completely new products in the new market (mean 3.34) and introduced new technologies successfully into the industry (mean3.27) but on the other hand this companies have less ability to create new techniques skills (mean2.93) and create new procedure skills (mean 2.94). Also the results from table 4 show that the target companies improving the existing products more than their competitors (mean 3.80) and improving the existing process more than their competitors (mean 3.77). Finally, the results in general indicate that the target companies achieved incremental innovation more than radical innovation.

\subsection{Hypotheses Testing}

In order to testing the study hypotheses a multiple regression was used. Table 5 presents the model summary and table 6 presents ANOVA analysis and tables $(7,8$ and 9$)$ presents beta and $t$ values for the study hypotheses.

Table 5. The model summary

\begin{tabular}{llllll}
\hline Model & R & R Square & $\begin{array}{l}\text { Adjusted } \\
\text { Square }\end{array}$ & R & Std. Error of The Estimate \\
\hline 1 & 0.873 & 0.754 & 0.705 & 0.345 \\
\hline
\end{tabular}

*Predictors: (Constant), Commitment, Compatibility, Capabilities.

As shown in table 5 the results indicate that the value of $\mathrm{R}$ square is $(0.754)$ which means that the model explains $(0.754)$ from the variance in the dependent variable (perceived firm innovation) by strategic alliance partner characteristics.

Table 6. ANOVA analysis

\begin{tabular}{llllll}
\hline Model & Sum of Squares & Df & Mean Square & F & Sig. \\
\hline 1 Regression & 330.270 & 3 & 47.251 & 1086.120 & 0.000 \\
Residual & 25.840 & 118 & 0.055 & & \\
Total & 356.120 & 121 & & & \\
\hline
\end{tabular}

*Predictors: (Constant), Commitment, Compatibility, Capabilities.

**Dependent Variable: Perceived Innovation. 
As shown in table 6 the results indicate that the value of $(F)$ is $(1086.120)$ with significant $(0.000)$ which is lower than the specified value $(0.05)$ so the model is fit and acceptable.

Table 7. Beta and $t$ values for the main hypothesis

\begin{tabular}{|c|c|c|c|c|c|}
\hline \multirow[t]{2}{*}{ Model } & \multicolumn{2}{|c|}{ Unstandardized Coefficients } & \multirow[t]{2}{*}{ Standardized Coefficients Beta } & \multirow[t]{2}{*}{ t. } & \multirow[t]{2}{*}{ Sig. } \\
\hline & B & Std. Error & & & \\
\hline 1 (Constant) & 0.059 & 0.046 & & & \\
\hline Compatibility & 0.206 & 0.013 & 0.268 & 18.813 & 0.000 \\
\hline Complementarity & 0.433 & 0.019 & 0.456 & 24.719 & 0.000 \\
\hline Commitment & 0.135 & 0.016 & 0.154 & 9.492 & 0.000 \\
\hline
\end{tabular}

*Dependent Variable: Perceived Innovation.

As shown in table 7 the results of multiple regression analysis indicate that the alliance partners characteristics effects firm innovation. The values of beta and t-tests show that the compatibility, complementarity, and commitment had a positive impact on firm innovation at $(\alpha \leq 0.05)$. And the highest impact was for complementarity (beta 0.456 ) and then compatibility (beta 0.268 ) and the lowest impact for commitment (beta $0.154)$.

Table 8 . Beta and $t$ values for the first sub hypothesis

\begin{tabular}{|c|c|c|c|c|c|}
\hline \multirow[t]{2}{*}{ Model } & \multicolumn{2}{|c|}{ Unstandardized Coefficients } & \multirow[t]{2}{*}{ Standardized Coefficients Beta } & \multirow[t]{2}{*}{ t. } & \multirow[t]{2}{*}{ Sig. } \\
\hline & B & Std. Error & & & \\
\hline 1 (Constant) & 0.053 & 0.043 & & & \\
\hline Compatibility & 0.198 & 0.015 & 0.210 & 16.117 & 0.000 \\
\hline Complementarity & 0.410 & 0.014 & 0.440 & 22.418 & 0.000 \\
\hline Commitment & 0.122 & 0.011 & 0.141 & 8.293 & 0.000 \\
\hline
\end{tabular}

* Dependent Variable: Incremental Innovation.

As shown in table 8 the results of multiple regression analysis indicate that the alliance partners characteristics effects firm incremental innovation. The values of beta and t-tests show that the compatibility, complementarity, and commitment had a positive impact on firm incremental innovation at $(\alpha \leq 0.05)$. And the highest impact was for complementarity (beta 0.440 ) and then compatibility (beta 0.210) and the lowest impact for commitment (beta 0.141).

Table 9. Beta and $t$ values for the second sub hypothesis

\begin{tabular}{|c|c|c|c|c|c|}
\hline \multirow[t]{2}{*}{ Model } & \multicolumn{2}{|c|}{ Unstandardized Coefficients } & \multirow[t]{2}{*}{ Standardized Coefficients Beta } & \multirow[t]{2}{*}{ t. } & \multirow[t]{2}{*}{ Sig. } \\
\hline & B & Std. Error & & & \\
\hline 1 (Constant) & 0.062 & 0.074 & & & \\
\hline Compatibility & 0.172 & 0.017 & 0.183 & 12.920 & 0.000 \\
\hline Complementarity & 0.342 & 0.015 & 0.372 & 19.150 & 0.000 \\
\hline Commitment & 0.102 & 0.012 & 0.117 & 4.760 & 0.000 \\
\hline
\end{tabular}

* Dependent Variable: Radical Innovation.

As shown in table 9 the results of multiple regression analysis indicate that the alliance partners characteristics effects firm radical innovation. The values of beta and t-tests show that the compatibility, complementarity, and commitment had a positive impact on firm radical innovation at $(\alpha \leq 0.05)$. And the highest impact was for complementarity (beta 0.372 ) and then compatibility (beta 0.183 ) and the lowest impact for commitment (beta $0.117)$.

\section{Recommendations}

Based on the results reached the study recommending that the companies that seeking for innovation through a strategic alliances must select the appropriate partner who has a complementary capabilities that contribute non 
overlapping resources to the relationship, and a partner who has the unique competencies; and the partner who has a compatible strategic objectives, organization culture and management style; and the partner who has a strong sense of commitment for the alliance.

\section{References}

Benner, M. J., \& Tushman, M. L. (2003). Exploitation, Exploration, and Process Management: The Productivity Dilemma Revisited. The Academy of Management Review, 28(2), 238-256. http://dx.doi.org/10.2307/30040711

Bierly, P. E., \& Gallagher, S. (2007). Explaining Alliance Partner Selection: Fit, Trust and Strategic Expediency. Long Range Planning, 40, 134-153. http://dx.doi.org/10.1016/j.lrp.2007.03.001

Byrne, J. (1993, February). The Virtual Corporation. Business Week, 98-102.

Caner, T., \& Tyler, B. B. (2013). Alliance Portfolio R\&D Intensity and New Product Introduction. American Journal of Business, 28(1), 38-63. http://dx.doi.org/10.1108/19355181311314761

Carnegie, R., \& Butlin, M. (1993). Managing the Innovative Enterprise: Australian Companies Competing against the World's best. Business Council of Australia, Melbourne.

Chandy, R. K., \& Tellis, G. J. (2000). The Incumbent's Curse? Incumbency, Size, and Radical Product Innovation. Journal of Marketing, 64(3), 1-17. http://dx.doi.org/10.1509/jmkg.64.3.1.18033

Child, J., \& Faulkner, D. (1998). Strategies of Cooperation: Managing Alliances, Networks, and Joint Ventures. New York: Oxford University Press.

Cui, A. S., \& O'Connor, G. (2012). Alliance Portfolio Resource Diversity and Firm Innovation. Journal of Marketing, 76(4), 24-43. http://dx.doi.org/10.1509/jm.11.0130

Danneels, E. (2002). The Dynamics of Product Innovation and Firm Competences. Strategic Management Journal, 23(12), 1095-1121. http://dx.doi.org/10.1002/smj.275

Das, T. K., \& Teng, B. (1998). Between Trust and Control: Developing Confidence in Partner Cooperation in Alliances. Academy of Management Review, 23(3), 491-512.

Deeds, D. L., \& Rothaermel, F. T. (2003). Honeymoons and Liabilities: The Relationship between Age and Performance in Research and Development Alliances. Journal of Product Innovation Management, 20(6), 468-484. http://dx.doi.org/10.1111/1540-5885.00043

Dewar, R. D., \& Dutton, J. E. (1986). The Adoption of Radical and Incremental Innovations: An Empirical Analysis. Management Science, 32(11), 1422-1433. http://dx.doi.org/10.1287/mnsc.32.11.1422

Dosi, G. (1982). Technological Paradigms and Technological Trajectories. Research Policy, 11(3), 147-162. http://dx.doi.org/10.1016/0048-7333(82)90016-6

Dyer, J., \& Singh, H. (1998). The Relational View: Cooperative Strategy and Sources of Interorganizational Competitive Advantage. Academy of Management Review, 23(4), 660-679.

Ettlie, J. E. (1983). Organizational Policy and Innovation among Suppliers to the Food Processing Sector. Academy of Management Journal, 26(1), 27-44. http://dx.doi.org/10.2307/256133

Ettlie, J. E., Bridges, W. P., \& O'Keefe, R. D. (1984). Organization Strategy and Structural Differences for Radical versus Incremental Innovation. Management Science, 30(6), 682-695. http://dx.doi.org/10.1287/mnsc.30.6.682

Faems, D., Looy, B., \& Debackere, K. (2005). Interorganizational Collaboration and Innovation: Toward a Portfolio Approach. Journal of Product Innovation Management, 22(3), 238-250. http://dx.doi.org/10.1111/j.0737-6782.2005.00120.x

Garcia, R., \& Calantone, R. (2002). A Critical Look at Technological Innovation Typology and Innovativeness Terminology. Journal of Product Innovation Management, 19(2), 110-132. http://dx.doi.org/10.1111/1540-5885.1920110

Gatignon, H., Tushman, M. L., Smith, W., \& Anderson, P. (2002). A Structural Approach to Assessing Innovation: Construct Development of Innovation Locus, Type, and Characteristics. Management Science, 48(9), 1103-1122. http://dx.doi.org/10.1287/mnsc.48.9.1103.174

Gulati, R. (1998). Alliances and Networks. Strategic Management Journal, 19(4), 293-317. http://dx.doi.org/10.1002/(SICI)1097-0266(199804)19:4<293::AID-SMJ982>3.0.CO;2-M 
Hagen, R. (2002). Globalization, University Transformation and Economic Regeneration. A UK Case Study of Public/Private Sector Partnership. International Journal of Public Sector Management, 15(3), 204-218. http://dx.doi.org/10.1108/09513550210423370

Harrigan, K. R. (1988). Joint Ventures and Competitive Strategy. Strategic Management Journal, 9(2), 141-158. http://dx.doi.org/10.1002/smj.4250090205

Herbig, P. A. (1994). The Innovation Matrix: Culture and Structure Prerequisites to Innovation. Westport, CT: Quorum Books.

Hitt, M. A., Ireland, R. D., \& Hoskisson, R. E. (1997). Strategic Management: Competitiveness and Globalization (2nd ed.). Minneapolis-Saint Paul: West Publishing. http://dx.doi.org/10.1002/(SICI)1097-0266(199702)18:2<159::AID-SMJ870>3.0.CO;2-X

Hitt, M. A., Tyler, B. B., Hardee, C., \& Park. D. (1995). Understanding Strategic Intent in the Global Marketplace. The Academy of Management Executive, 9(2), 12-19.

Ireland, R. D., Hitt, M. A., \& Vaidyanath, D. (2002). Alliance Management as a Source of Competitive Advantage. Journal of Management, 28(3), 413-446. http://dx.doi.org/10.1177/014920630202800308

Kale, P., \& Singh, H. (2009). Managing Strategic Alliances: What Do We Know Now, and Where Do We Go from Here? Academy of Management Perspectives, 23(3), 45-62. http://dx.doi.org/10.5465/AMP.2009.43479263

Kanter, R. M. (1994). Collaborative Advantage: The Art of Alliances. Harvard Business Review, 72(4), 96-108.

Kelly, D., \& Rice, M. (2002). Advantage beyond Founding: The Strategic Use of Technologies. Journal of Business Venturing, 17(1), 41-57. http://dx.doi.org/10.1016/S0883-9026(00)00053-7

Kimberly, J. R., \& Evanisko, M. J. (1981). Organizational Innovation: The Influence of Individual, Organizational, and Contextual Factors on Hospital Adoption of Technological and Administrative Innovations. Academy of Management Journal, 24(4), 689-713. http://dx.doi.org/10.2307/256170

Koberg, C. S., Detienne, D. R., \& Heppard, K. A. (2003). An Empirical Test of Environmental, Organizational, and Process Factors Affecting Incremental and Radical Innovation. The Journal of High Technology Management Research, 14(1), 21-45. http://dx.doi.org/10.1016/S1047-8310(03)00003-8

Kotabe, M., \& Swan, K. S. (1995). The Role of Strategic Alliances in High-Technology New Product Development. Strategic Management Journal, 16(8), 621-636. http://dx.doi.org/10.1002/smj.4250160804

Li, Y., Liu, Y., Li, M., \& Wu, H. (2008). Transformational Offshore Outsourcing: Empirical Evidence from Alliances in China. Journal of Operations Management, 26(2), 257-274. http://dx.doi.org/10.1016/j.jom.2007.02.011

Mason, J. C. (1993). Strategic Alliances: Partnering for Success. Management Review, 82(5), 10-15.

Nystrom, H. (1990). Technological and Market Innovation: Strategies for Product and Company Development. London: John Wiley \& Sons.

Pansiri, J. (2008). The Effects of Characteristics of Partners on Strategic Alliance Performance in the SME Dominated Travel Sector. Tourism Management, 29(1), 101-115. http://dx.doi.org/10.1016/j.tourman.2007.03.023

Phelps, C. C. (2010). A Longitudinal Study of the Influence of Alliance Network Structure and Composition on Firm Exploratory Innovation. Academy of Management Journal, 53(4), 890-913. http://dx.doi.org/10.5465/AMJ.2010.52814627

Qing, Z., Weijing, D., \& Wenhui, H. (2012). Technological Standard Alliance in China: Partner Selection and Innovation Performance. Journal of Science and Technology Policy in China, 3(3), 196-209. http://dx.doi.org/10.1108/17585521211268655

Reuer, J. J. (1999, October 4). Collaborative Strategy: The Logic of Alliances. Mastering Strategy, 12-13.

Sampson, R. C. (2007). R\&D Alliances and Firm Performance: The Impact of Technological Diversity and Alliance Organization on Innovation. Academy of Management Journal, 50(2), 364-386. http://dx.doi.org/10.5465/AMJ.2007.24634443

Schilling, M. A. (2008). Strategic Management of Technological Innovation. Boston: McGraw Hill. 
Shah, R. H., \& Swaminathan, V. (2008). Factors Influencing Partner Selection in Strategic Alliances: The Moderating Role of Alliance Context. Strategic Management Journal, 29(5), 471-94. http://dx.doi.org/10.1002/smj.656

Shamdasani, P. N., \& Sheth, J. N. (1995). An experimental Approach to Investigating Satisfaction and Continuity in Marketing Alliances. European Journal of Marketing, 29(4), 6-23. http://dx.doi.org/10.1108/03090569510086620

Sivadas, E., \& Dwyer, F. R. (2000). An Examination of Organizational Factors Influencing New Product Success in Internal and Alliance-Based Processes. Journal of Marketing, 64(1), 31-49. http://dx.doi.org/10.1509/jmkg.64.1.31.17985

Swink, M., Talluri, S., \& Pandejpong, T. (2006). Faster, Better, Cheaper: A Study of NPD Project Efficiency and Performance Tradeoffs. Journal of Operations Management, 24(5), 542-562. $\mathrm{http}: / / \mathrm{dx}$. doi.org/10.1016/j.jom.2005.09.004

Utterback, J. (1994). Mastering the Dynamics of Innovation. Boston: Harvard Business School Press.

Wu, W. Y., Shih, H., \& Chanm, H. (2009). The Analytic Network Process for Partner Selection Criteria in Strategic Alliances. Expert Systems with Applications, 36, 446-465.

Wuyts, S., Dutta, S., \& Stremersch, S. (2004). Portfolios of Interfirm Agreements in Technology-Intensive Markets: Consequences for Innovation and Profitability. Journal of Marketing, 68(2), 88-100. http://dx.doi.org/10.1509/jmkg.68.2.88.27787

Zheng, S., Li, H., \& Wu, X. (2013). Network Resources and the Innovation Performance: Evidence from Chinese Manufacturing Firms. Management Decision, 51(6), 1207-1224. http://dx.doi.org/10.1108/MD-02-2012-0102

\section{Copyrights}

Copyright for this article is retained by the author(s), with first publication rights granted to the journal.

This is an open-access article distributed under the terms and conditions of the Creative Commons Attribution license (http://creativecommons.org/licenses/by/3.0/). 